\begin{tabular}{|c|c|c|}
\hline UNMAS DENPASAR & $\begin{array}{l}\text { Sphota: Jurnal Linguistik dan Sastra } \\
\text { Vol. 12, no.2 (September 2020), pp. 48-57, } \\
\text { doi : } \text { https://doi.org/10.36733/sphota.v12i2.944 } \\
\text { Fakultas Bahasa Asing, Universitas Mahasaraswati, Denpasar, Bali, } \\
\text { Indonesia }\end{array}$ & Sphotal \\
\hline
\end{tabular}

\title{
THE PERCEPTION OF EFL STUDENTS TO THE USE OF CODE- SWITCHING IN CLASSROOM
}

\author{
I Gusti AgungVony Purnama \\ ITB STIKOM Bali \\ vony@stikom-bali.ac.id
}

\begin{abstract}
Language plays an important role in our everyday lives. It cannot be separated from our daily communication. English is an international language and used by all people in the world to communicate with each other. This language is as a foreign language for the EFL students particularly in Indonesia. Therefore, in teaching this language, code-switching usually occurs. This study aims to find the perception of the EFL students towards the use of code switching in the classroom. The students under concern were the classroom of English subject for the higher education. The method of collecting data of this study was directly from the questionnaire of the students. Qualitative research was applied in this study in analyzing the data. There were thirty-one students involved in the questionnaires after they finished the class of English subject. The data from the questionnaire was analyzed based on theory of Cohen (2010) to investigate the perception of the students on the use of code switching in learning English. The result showed that students give the positive perceptionregarding to the use of code-switching in teaching and learning English as a foreign language. It is hoped this positive perception on the use of code switching can be used in teaching and learning English for EFL students.
\end{abstract}

Keywords: Code-Switching, EFL Students, Perception

\section{Introduction}

The use of code switching is always as an issue in teaching and learning foreign language whether this can improve the students understanding on their target language or not. This method is usually used in the activity of teaching and learning language. Code-switching is the situation when the speakers use their target language and their first language back and forth. Lin (2013) defines code-switching as the use of two languages code by either teachers or students in classroom setting. Codeswitching as debatable phenomenon can be viewed based on pro and cons side. According to Üstunel (2016), Code-switching, viewed by affirmatives, it is believed to bridge the teaching and learning process. However, code-switching is a normal used since 1980s by most scholars and they have come regard it as a natural product of bilingual and multilingual use of language. The use of code-switching in teachinglearning process is a normal phenomenon. It is mentioned by Jingxia (2010), that the code-switching overuse may affect to the students' optimization of using English compared to the class which uses English all the time. However, the use of code switching might help the students in learning English, since they still have only a few vocabularies. Besides, the other reason is, the students are not familiar yet with the structure in their target language, and therefore, in explaining the target language, it is better and important to switch the code, to get the students understanding in the first place. Moreover, in delivering the lesson particularly English as the foreign 
language, if the teacher always uses their target language in the classroom, it seems that the students mostly feel tensed and stressful since they have not mastered it yet then it can reduce their interesting in attending the class. This situation is not expected by the language teacher. However, on the other hand, according to Zhu (2008), it is afraid that code-switching distributes more disadvantages and may affect the way students communicate later. Students may think that practicing the target language is not important since the teacher always gives the translation or switches the codes. Referring to the above phenomenon, this study was focused to see the students' perception regarding to the use of code switching in the classroom by the English lecturers. The findings of this study are expected to be used as a reference in teaching an English as a foreign language.

\section{Materials and Method}

This phase is to explain the literature reviews used in this study. Besides that, the research method of this study is also described in this part.

\section{Previous Research Review}

There were two previous studies from the two different journals that are already published. The first Journal is written by Thomas WahyuPrabowoMukti and RetnoMuljani (2016) with the title "Code-switching in the Instructions of English Language Education Study Program Lecturers". This was published in LLT Journal Vol. 19 No. 1 - April 2016. The aims of this research were to find out the types of code-switching that the ELESP lecturers employ in their instructional languages are and second and to find out the reason for employing the code-switching in their instructional language. The results of this study showed that the type of situational and metaphorical code-switching was employed by the lecturers. In addition, the writer also found that the participants of the study code-switched for the reasons which can be classified into addressee, topic, emphasis, persuasion, solidarity, affection, nature of the subject and strategy. The second result of this study also found that the purpose of code-switching in lecturers' instructional languages was mainly for the students' understanding. The second article is written by $\mathrm{Md}$. Obaidullah (2016) with the title "Code-Switching in EFL Classroom: A Bangladeshi Perspective". This was published in Theory and Practice in Language Studies Journal, Vol.6, No.5, pp. 924-934, May 2016. This paper aims to expose the plausible reasons behind the application of first language (L1) in English as Foreign Language (EFL) Classrooms. The findings of this survey show that a switch to L1, whether initiated by the teachers or the students, makes the lesson or topic discussed in the class more comprehensible.Those results of studies in two difference journals are as references for the writer in finding, analyzing and describing the results of this study. There are some similarities between those two studies with this study. The similarities are on the research object and the aim of this study, which is to find the students' perception toward the use of code-switching in classroom. The second journal is written by R. Rahmina, RoswitaLumbanTobing, (2016) with the tittle "PenggunaanAlihKode (Code-switching) dalamPembelajaranBahasaInggris di MA Mu'AllimaatMuhammadiyah Yogyakarta". 
This was published in Ling Tera Volume 3 - Number 2, October 2016, (191202). This journal is written in Bahasa. This research aims to describe the type of code-switching that was happened in learning English and the background factor of using the code-switching in English teaching and learning process in MA Mu"allimaat Muhammadiyah Yogyakarta. The result of this study showed that the use of code-switching in English subject in MA Mueeallimaat Muhammadiyah Yogyakarta happened in 166 data. Next, the data was divided into two types of codeswitching, they were; (1) intra-sentential code-switching was happened in 61 data (37\%), and (2) inter-sentential code-switching was happened in 105 data (63\%). Another result showed that the linguistics and non -linguistics factors as the background in using the code-switching. The dominant factor was the linguistics factor as the background of the students' lack understanding.

\section{Method}

In conducting this research, qualitative research was used. According to Creswell (2014), qualitative research is an approach for exploring and understanding the meaning individuals or groups ascribe to a social or human problem. In this study, to support the qualitative data, questionnaires were used as the instrument of this study. The questionnaires were adapted from the questionnaires in Obaidullah (2016). The participants were asked to fill the questionnaires based on their perception. The data forms the questionnaires then analyzed to figure out the perception of the students regarding to the use of code switching in teaching and learning English. The participants of this study were thirty-one (31) higher education students. They were in the second semester. They must take two English subjects along their four years' study. In semester 1 they got English I and in semester two they got English II. This study used a Likert Scale as the type of the questionnaire. According to Cohen (2010) a Likert Scale provides a range of responses to a given question or statement.

\section{Result and Discussion}

This phase is presenting the result and discussion of this study. The students' answers toward the questionnaires are presented in the form of table.

\section{Result}

As the purpose of this study is also to find out the students' response on the use of code switching in learning English, below is the graph that shows their response. There were fifteen questions to be answered by the students regarding to the use of code switching.

Table 3.1

Result of Question 1 "Teacher switch code in the classroom"

\begin{tabular}{|l|l|c|c|c|c|c|c|}
\hline \multicolumn{2}{|c|}{ Response } & $\begin{array}{c}\text { Strongly } \\
\text { Agree }\end{array}$ & Agree & Undecided & Disagree & $\begin{array}{c}\text { Strongly } \\
\text { Disagree }\end{array}$ & Total \\
\hline Q1 & Frequency & 9 & 21 & 1 & & & 31 \\
\cline { 2 - 8 } & Percentage & 29.03 & 67.7 & 3.2 & & & 100 \\
\hline
\end{tabular}

Table 3.2

Result of Question 2 "Teacher uses frequent code switching in the class for beginnerstudent" 
THE PERCEPTION OF EFL STUDENTS TO THE USE OF CODE-SWITCHING IN

CLASSROOM,

I Gusti Agung Vony Purnama

\begin{tabular}{|l|l|c|c|c|c|c|c|}
\hline \multicolumn{2}{|c|}{ Response } & $\begin{array}{c}\text { Strongly } \\
\text { Agree }\end{array}$ & Agree & Undecided & Disagree & $\begin{array}{c}\text { Strongly } \\
\text { Disagree }\end{array}$ & Total \\
\hline \multirow{2}{*}{ Q2 } & Frequency & 9 & 19 & 3 & & & 31 \\
\cline { 2 - 8 } & Percentage & 29.03 & 61.29 & 9.7 & & & 100 \\
\hline
\end{tabular}

Table 3.3

Result of Question 3 "Teacher reduces the frequency of code switching when the student become more senior"

\begin{tabular}{|l|l|c|c|c|c|c|c|}
\hline \multicolumn{2}{|c|}{ Response } & $\begin{array}{c}\text { Strongly } \\
\text { Agree }\end{array}$ & Agree & Undecided & Disagree & $\begin{array}{c}\text { Strongly } \\
\text { Disagree }\end{array}$ & Total \\
\hline Q3 & Frequency & 4 & 17 & 6 & 4 & & 31 \\
\cline { 2 - 8 } & Percentage & 12.9 & 54.8 & 19.3 & 12.9 & & 100 \\
\hline
\end{tabular}

Table 3.4

Result of Question 4 "Code switching from English to Indonesian, teacher can better explain the grammatical terms, new, and familiar topic and vocabulary in the text"

\begin{tabular}{|l|l|c|c|c|c|c|c|}
\hline \multicolumn{2}{|c|}{ Response } & $\begin{array}{c}\text { Strongly } \\
\text { Agree }\end{array}$ & Agree & Undecided & Disagree & $\begin{array}{c}\text { Strongly } \\
\text { Disagree }\end{array}$ & Total \\
\hline Q4 & Frequency & 14 & 15 & 2 & & & 31 \\
\cline { 2 - 8 } & Percentage & 45.2 & 48.4 & 6.45 & & & 100 \\
\hline
\end{tabular}

Table 3.5

Result of Question 5 "By code switching from English to Indonesian, teacher can make the lesson content taught in the class more comprehensible"

\begin{tabular}{|l|l|c|c|c|c|c|c|}
\hline \multicolumn{2}{|c|}{ Response } & $\begin{array}{c}\text { Strongly } \\
\text { Agree }\end{array}$ & Agree & Undecided & Disagree & $\begin{array}{c}\text { Strongly } \\
\text { Disagree }\end{array}$ & Total \\
\hline Q5 & Frequency & 11 & 17 & 3 & & & 31 \\
\cline { 2 - 8 } & Percentage & 35.5 & 54.8 & 9.7 & & & 100 \\
\hline
\end{tabular}

Table 3.6

Result of Question 6 "By code switching from English to Indonesian, teacher can better clarify task instruction"

\begin{tabular}{|l|l|c|c|c|c|c|c|}
\hline \multicolumn{2}{|c|}{ Response } & $\begin{array}{c}\text { Strongly } \\
\text { Agree }\end{array}$ & Agree & Undecided & Disagree & $\begin{array}{c}\text { Strongly } \\
\text { Disagree }\end{array}$ & Total \\
\hline \multirow{2}{*}{ Q6 } & Frequency & 16 & 13 & 1 & 1 & & 31 \\
\cline { 2 - 8 } & Percentage & 51.6 & 41.9 & 3.2 & 3.2 & & 100 \\
\hline
\end{tabular}

Table 3.7

Result of Question 7 "Teacher can better discipline the students by code switching from English to Indonesian"

\begin{tabular}{|l|l|c|c|c|c|c|c|}
\hline \multicolumn{2}{|c|}{ Response } & $\begin{array}{c}\text { Strongly } \\
\text { Agree }\end{array}$ & Agree & Undecided & Disagree & $\begin{array}{c}\text { Strongly } \\
\text { Disagree }\end{array}$ & Total \\
\hline \multirow{2}{*}{ Q7 } & Frequency & 8 & 12 & 10 & 1 & & 31 \\
\cline { 2 - 8 } & Percentage & 25.8 & 38.7 & 32.2 & 3.2 & & 100 \\
\hline
\end{tabular}

Table 3.8

Result of Question 8 "Continuous use of English in the class makes the class tedious and monotonous"

\begin{tabular}{|c|l|c|c|c|c|c|c|}
\hline \multicolumn{2}{|c|}{ Response } & $\begin{array}{c}\text { Strongly } \\
\text { Agree }\end{array}$ & Agree & Undecided & Disagree & $\begin{array}{c}\text { Strongly } \\
\text { Disagree }\end{array}$ & Total \\
\hline Q8 & Frequency & 7 & 11 & 10 & 3 & & 31 \\
\hline
\end{tabular}


Table 3.9

Result of Question 9 "Code switching makes my lesson enjoyable

\begin{tabular}{|l|l|c|c|c|c|c|c|}
\hline \multicolumn{2}{|c|}{ Response } & $\begin{array}{c}\text { Strongly } \\
\text { Agree }\end{array}$ & Agree & Undecided & Disagree & $\begin{array}{c}\text { Strongly } \\
\text { Disagree }\end{array}$ & Total \\
\hline Q9 & Frequency & 9 & 20 & 2 & & & 31 \\
\cline { 2 - 8 } & Percentage & 29 & 64.5 & 6.45 & & & 100 \\
\hline
\end{tabular}

Table 3.10

Result of Question 10 "I feel satisfied with my learning process when teacher switch codes"

\begin{tabular}{|c|l|c|c|c|c|c|c|}
\hline \multicolumn{2}{|c|}{ Response } & $\begin{array}{c}\text { Strongly } \\
\text { Agree }\end{array}$ & Agree & Undecided & Disagree & $\begin{array}{c}\text { Strongly } \\
\text { Disagree }\end{array}$ & Total \\
\hline \multirow{2}{*}{ Q10 } & Frequency & 6 & 20 & 4 & 1 & & 31 \\
\cline { 2 - 8 } & Percentage & 19.35 & 64.5 & 12.9 & 3.2 & & 100 \\
\hline
\end{tabular}

Table 3.11

Result of Question 11 "Code switching gives me comfort while understanding difficult topics or instruction"

\begin{tabular}{|c|l|c|c|c|c|c|c|}
\hline \multicolumn{2}{|c|}{ Response } & $\begin{array}{c}\text { Strongly } \\
\text { Agree }\end{array}$ & Agree & Undecided & Disagree & $\begin{array}{c}\text { Strongly } \\
\text { Disagree }\end{array}$ & Total \\
\hline \multirow{2}{*}{ Q11 } & Frequency & 12 & 17 & 2 & & & 31 \\
\cline { 2 - 8 } & Percentage & 38.7 & 54.8 & 6.45 & & & 100 \\
\hline
\end{tabular}

Table 3.12

Result of Question 12 "Code switching helps me feel less tensed"

\begin{tabular}{|c|l|c|c|c|c|c|c|}
\hline \multicolumn{2}{|c|}{ Response } & $\begin{array}{c}\text { Strongly } \\
\text { Agree }\end{array}$ & Agree & Undecided & Disagree & $\begin{array}{c}\text { Strongly } \\
\text { Disagree }\end{array}$ & Total \\
\hline \multirow{2}{*}{ Q12 } & Frequency & 4 & 17 & 8 & 2 & & 31 \\
\cline { 2 - 8 } & Percentage & 12.9 & 54.8 & 25.8 & 6.45 & & 100 \\
\hline
\end{tabular}

Table 3.13

Result of Question 13 "Code switching makes me feel less lost during the lesson"

\begin{tabular}{|c|l|c|c|c|c|c|c|}
\hline \multicolumn{2}{|c|}{ Response } & $\begin{array}{c}\text { Strongly } \\
\text { Agree }\end{array}$ & Agree & Undecided & Disagree & $\begin{array}{c}\text { Strongly } \\
\text { Disagree }\end{array}$ & Total \\
\hline Q13 & Frequency & 1 & 14 & 10 & 6 & & 31 \\
\cline { 2 - 8 } & Percentage & 3.2 & 45.2 & 3.2 & 19.35 & & 100 \\
\hline
\end{tabular}

Table 3.14

Result of Question 14 "Do you favor teacher's code switching from English to Indonesian in the classroom?'

\begin{tabular}{|c|l|c|c|c|c|c|c|}
\hline \multicolumn{2}{|c|}{ Response } & $\begin{array}{c}\text { Strongly } \\
\text { Agree }\end{array}$ & Agree & Undecided & Disagree & $\begin{array}{c}\text { Strongly } \\
\text { Disagree }\end{array}$ & Total \\
\hline Q14 & Frequency & 4 & 23 & 4 & & & 31 \\
\cline { 2 - 8 } & Percentage & 12.9 & 74.2 & 12.9 & & & 100 \\
\hline
\end{tabular}

Table 3.15

Result of Question 15 “Teacher's code switching accelerates learning process of the student 


\begin{tabular}{|c|l|c|c|c|c|c|c|}
\hline \multicolumn{2}{|c|}{ Response } & $\begin{array}{c}\text { Strongly } \\
\text { Agree }\end{array}$ & Agree & Undecided & Disagree & $\begin{array}{c}\text { Strongly } \\
\text { Disagree }\end{array}$ & Total \\
\hline \multirow{2}{*}{ Q15 } & Frequency & 5 & 22 & 4 & & & 31 \\
\cline { 2 - 8 } & Percentage & 16.1 & 70.98 & 12.9 & & & 100 \\
\hline
\end{tabular}

\section{Discussion}

From the above table, it shows the response of the students in the classroom when the teacher switches the code. The question of number one is 'Teacher switch code in the classroom'. There are $67.7 \%$ students 'agree' when the teacher switches the codes in the classroom, $29.03 \%$ students are 'strongly agree', and the rest $3.2 \%$ students are 'undecided'. From this result, here can be seen that the students feel comfortable when the teacher use two languages, they are their first language and their target language. This is because they do not use their target language in their everyday conversation. Therefore, it is difficult for them to understand their target language without switch the code into their first language. This is also the way to improve their interest in learning English language. The second question is 'Teacher uses frequent code switching in the class for beginner student'. There are $61.29 \%$ students 'agree' with this question, 29.03\% students are 'strongly agree', and 9.7\% are 'undecided' with this question. From this result, It seems that they like the idea of using the code switching when they are in the first semester though they already learned this language from elementary school. Here in this program, the students must take English subject in two semesters; they are English 1 and English 2. In the first semester, the syllabus is about the general English and the syllabus of the English 2 is about the English for Special Purpose, particularly in terms of technology of computer. In each English class, the students are expected to be active in the class during the learning process. Sometimes it is not an easy task for the teacher to push the students' motivation and it depends on the topic. The use of code switching frequently can be very helpful for the students in understanding the task and also for the teacher.

In the third sentence, the question is related with the second question, 'Teacher reduces the frequency of code switching when the students become more senior'. There are $54.8 \%$ students 'agree', $19.3 \%$ 'undecided' and $12.9 \%$ 'strongly agree and disagree'. From this result, more than 50\% students agree with the question, it seems that they realize that they must improve their understanding in using English when they are in the second semester and become senior since they have already experience when the teacher used the code switching in the first semester. Based on this finding, it seems that the students have a confidence in learning their target language. They get use to listen the teacher's explanation in English or minimizing to switch the code into their first language. They must have their own responsibility in improving their learning process.

The fourth question is 'By code switching from English to Indonesian, teacher can better explain the grammatical terms, new, and familiar topic and vocabulary in the text'. There are $48.4 \%$ students 'agree' with this, $45.2 \%$ are 'strongly agree', and $6.45 \%$ are 'undecided'. Grammatical term is the most difficult part of the lesson that the EFL students usually afraid of. In explaining this difficult part of learning English, students really need to be given the explanation clearly in both languages, English and Indonesian. Teacher can translate some points into 
Indonesian to make sure that the students get the point of the lesson. Moreover, it is also important to give an explanation about the similarity and differences between their first language and their target language before starting to study grammar. Their first language which is Indonesian language has some similarities and some differences with their target language or English. This is the basic materials that the teacher must explain in the students' first language to get their understanding.

The fifth question is 'By code switching from English to Indonesian, teacher can make the lesson content taught in the class more comprehensible'. Most of the students are 'agree' with this, the percentage is $54.8 \%$. The second response is 'strongly agree' with $35.5 \%$, then it is followed by 'undecided', it is only $9.7 \%$. From this result, it is clearly seen that the students are more comfortable when the teacher switch the code. By switching the code, teacher can get the students' attention to the lesson content. It is not an easy job to get their attention in the classroom even for one and half hour. Students usually only concentrate to the content less than one hour, and it might reduce when they do not understand what the teacher says in front of the class. Switching the code is a solution and they agree with this method of teaching to make the lesson content more comprehensible.

The sixth question is 'By code switching from English to Indonesian, teacher can better clarify task instruction'. For this question, the students are 'strongly agree', then followed by 'agree'. They are $51.6 \%$ of 'strongly agree', and $41.9 \%$ 'agree'. There are also 'undecided' and 'disagree' answers for this question, and both are $3.2 \%$ of the students. From this result, students are strongly agreed when the teacher switch the code into their first language when clarifying the task instruction. The reason must be because of the task is the important part of the scoring system that the teacher usually uses for their final score. If the students do not understand the task instruction, they will be lost, and they have to take the consequences of their mistake. Absolutely, one of the teacher's tasks is to make the students get the point of the instruction. By switching the code, it is hope that they will understand the instruction then they can make the task correctly according to the instruction. Therefore, it is better to clarify the task or instruction that the students must do in their first language to avoid the incorrect feedback from the students regarding to the task.

In terms of the students' discipline, the code switching has an important role. It is proved by the seventh question 'Teacher can better discipline the students by code switching from English to Indonesian'. There are 38.7\% 'agree' with this, $25.8 \%$ are 'strongly agree', then ' $32.3 \%$ 'undecided', and the last is 'disagree' with $3.2 \%$. Based on the result of this question, it is found that more students agree with this although not more than $40 \%$ while the percentage of 'undecided' is in the second place. Teacher can discipline the students by switching the code into their first language; it means that teacher can use the language that is familiar for the students. It seems very useful to get the students' attention if teacher switch the coed into their first language. Discipline is the key to get to the goal or the purpose of the learning process. Therefore, this is very important besides explaining the lesson.

Teacher needs to use code switching in teaching the EFL; therefore, the class will not be boring. This statement is supported on the eight question 'Continuous use of English in the class makes the class tedious and monotonous'. Based on the above 
table, it shows that the percentage of 'agree' students is $35.5 \%$, and some of them are also 'strongly agree' with that question and the percentage is $22.6 \%$, but there are also some students' responses are 'undecided' with the percentage of $32.3 \%$. Only few of them response for 'disagree' with $9.7 \%$. From this result, it is a fact that in learning process particularly learning the foreign language can be so boring. Here, teacher's creativity is very needed in creating a comfortable situation during the learning process. Switching the code from English into the students' first language could be a good way to get the students attention and reduce the monotonous. Learning target language does not mean that teacher only have to teach using the target language, it is better to switch into the students' first language and then back to the target language, therefore, for some students who do not very understand the target language, they will not feel lost and bored. This way is also expected can build the students' motivation.

For the questions on number nine and ten, both of them have a similar positive statement regarding to the use of code switching by the teacher. The question of number nine is 'Code switching makes my lesson enjoyable', and the question of number ten is 'I feel satisfied with my learning process when teacher switch codes'. The percentages of 'agree' students for those questions are the same. It is $64.5 \%$ students 'agree' with those two questions. They also give a response for 'strongly agree', 'undecided' and 'disagree'. Their percentage is $29 \%$ and $19.35 \%$ for 'strongly agree', $6.45 \%$ and $12.9 \%$ for 'undecided', and $3.2 \%$ for 'disagree' is only found in question ten. Students do agree by switching the code, they feel enjoy learning the target language. Students might feel free to ask question in their first language if they do not understand the materials. The first important thing is how to make the students feel comfortable in learning the target language to make them understand the concept and the basic knowledge of the lesson. The goal of the learning process must be easier to achieve if the students feel enjoy and comfortable. Students will feel satisfied with their good achievement and improvement.

There are also the same percentage of 'agree' answer for the question of number eleven and twelve. The 'agree' percentage is $54.8 \%$ for both questions. The question of number eleven is almost similar with the question of number twelve in terms of the meaning. The question of number eleven is 'Code switching gives me comfort while understanding difficult topics or instruction', and question of number twelve is 'Code switching helps me feel less tensed'. It seems that since the students feel comfortable when the teacher switches the codes, it is then automatically affecting the students feeling. They do not feel stressful when the teacher switches the codes which are important to improve their ability. Besides the 'agree' response, there are also 'strongly agree' response, 'undecided', and 'disagree'. The smallest percentage is $6.45 \%$ for the 'disagree' response regarding to the question of number twelve. The percentage of 'strongly agree' for both of those questions are different significantly, they are $38.7 \%$ for question of number eleven, and $12.9 \%$ for the question of number twelve. For the response of 'undecided' is also different significantly for both of those questions. There is $6.45 \%$ for the question of number eleven, and $25.8 \%$ for the question of number twelve. On the other hand, there is still positive response from the students since most of them agree with the statements. 
For the question of number thirteen, there are $45.2 \%$ for 'agree' response, $19.35 \%$ for the 'disagree' response, and $3.2 \%$ for both 'strongly agree' and 'undecided' responses. The question is 'Code switching makes me feel less lost during the lesson'. Students may get lost when they do not know the meaning of the words that teacher uses in explaining the material during the learning process. It is not easy to open the dictionary every time they do not know the meaning of every single word that they are listening during the class. It might take time to check the dictionary and then it is impossible to be focused on the whole lesson. This situation can make them feel lost and frustration to follow the lesson. Most of the students, nowadays, they are easier to give up with the difficult situation. Therefore, to minimize the frustration, switching the codes after explaining the lesson in their target language might be very useful and helpful for them.

The fourteenth question is 'Do you favor teacher's code switching from English to Indonesian in the classroom?' The response shows that almost more than half students agree with this question. The percentage is $74.2 \%$, then it is followed by $12.9 \%$ for both of 'strongly agree', and 'undecided' responses. Based on this result, it shows that students support the teachers in switch the codes during the lesson. Teachers can systematically switch the code from English to Indonesian language to see the effectiveness of the learning process.

The last question is 'Teacher's code switching accelerates learning process of the student'. The students' response is positive as well as the previous question. There are $70.98 \%, 16.1 \%$, and $12.9 \%$ for 'agree', 'strongly agree', and 'undecided' responses. Switching the code from English to Indonesian will minimize the students' time in checking the dictionary to find the meaning of the words that there are not familiar. Students may depend only on teacher's code-switching to help them find out the meaning of the difficult words.

\section{Conclusion}

In conformity with the aim of this study, there was to find the EFL students' perception on the use of code-switching in the classroom. Based on the questionnaire it was found that the "Agree" answer got the highest number. It means that most of the students answered "Agree" in all questions. The finding shows that the highest answer in almost all questions was 'Agree'. This 'Agree' answer was chosen by the students in 14 questions, and only in 1 question has the highest "strongly agree" answer. From the questionnaire, then it can be concluded that the students give the positive perception regarding to the use of code-switching in teaching and learning English as a foreign language. This study has a small contribution on the same research area of code switching. It is hoped that there will be various and deep studies regarding to the use of code switching particularly for Indonesian EFL classroom.

\section{References}

Ahmad, B.H., \&Jussof, K. (2009). Teacher's code-switching in classroom instruction for low English Proficient Learners. English Language Teaching, 2(2), 49-55. doi: https://doi.org/10.5539/elt.v2p49.

Auer, P. (1984). Bilingual Conversation. Amsterdam: John Benjamins. 
Brice, A.; Brice, R. (2009). Language development: Monolingual and bilingual acquisition. Old Tappan, NJ: Merrill/Prentice Hall.

Cromdal, J. (2001). "Overlap in Bilingual Play: Some Implications of Code-Switching for Overlap Resolution". Research on Language and Social Interaction. 34 (4): 421-51.

Cromdal, J. (2004). "Building bilingual oppositions: Code-switching in children's disputes". Language in Society. 33 (1): 33-58.

Eller, M. (1992). "The Politics of Codeswitching and Language Choice". In C.Eastman. Codeswitching. Clevedon: Multilingual Matters.

Goldstein, B.; Kohnert, K. (2005). "Speech, language and hearing in developing bilingual children: Current findings and future directions". Language, Speech and Hearing Services in Schools. 36 (3): 264-67.

Gutierrez-Clellen, V. (1999). "Language choice in intervention with bilingual children". American Journal of Speech-Language Pathology. 8 (4): 291-302.

Hamers, F. \& Blanc, M. (2000). Bilinguality and Bilingualism. Cambridge University Press: Cambridge.

Hoffman, C. An Introduction to Bilingualism. New York: Longman.1991.

Cohen. (2010). Research Methods in Education: Fifth Edition, London: RoutledgeFalmer.

Kohnert, K.; Yim, D.; Nett, K.; Duran, P. F.; Duran, L. (2005). "Intervention with linguistically diverse preschool children: A focus on developing home language(s)". Language, Speech and Hearing Services in Schools. 36 (3): 251-63.

Lin, A. M. Y. (2013) Classroom code-switching: Three decades of research. Applied Linguistics Review, 4(1), 195-218.

Obaidullah, Md. (2016). Code Switching in EFL Classrooms: A Bangladeshi Perspective. Theory and Practice in Language Studies, Vol.6, No.5, pp.924-934.

Musk, N. J. (2012). "Performing bilingualism in Wales: Arguing the case for empirical and theoretical eclecticism". Pragmatics: Quarterly Publication of the International Pragmatics Association. 22 (4): 651-669.

Nassaji, H. (2015). Qualitative and Descriptive Research: Data Type Versus Data Analysis. Language Teaching Research, 19(2) 129, 129-132.

Nurhamidah, Fauziati, E., \&Supriyadi, S. (2018). Code-Switching in EFL Classroom: Is It Good or Bad?. Journal of English Education, 3(2), 78-88. doi: http://dx.doi.org/10.31327/jee.v3i2.861

Poplack, S. (1980). Sometimes I'll start a sentence in English y termino ${ }^{\sim}$ enespañol" Toward a typology of code-switching. Linguistics 18, 581-616.

Pujolar, J. (2000). Gender, Heteroglossia and Power. A Sociolinguistic Study of Youth Culture. Berlin: Walter de Gruyter.

Rampton, B. (1995). Crossing: Language and Ethnicity among Adolescents. London: Longman.

Sebba, Mark; Wooton, Tony (1998). "We, They and Identity: Sequential Versus Identity Related Explanation in Code Switching". In P. Auer. Code-Switching in Conversation: Language, Interaction, and Identity. London: Routledge. pp. 262-86.

Stapa, N. \& Khan, N. (2016). Functions of Code-Switching: A Case Study of A Mixed MalayChinese Family in the Home Domain, PertanikaJ.Soc. SCI. \& Hum. 24 (S), 181-194.

Üstunel, E. (2016). EFL classroom code-switching. Turkey: Palgrave Macmillan.

Uys, D., \& van Dulm, O. (2011). The Function of Classroom Code-Switching in the Siyanda District of the Northen Cape. Southern African linguistics and Applied Language Studies, 29(1), 6776. doi:https://doi.org/10.2989/16073614.2011.583159.

Weinreich, U. (1953). Languages in Contact. The Hague: Mouton.

Wei, L. (1998). "The 'Why' and 'How' Questions in the Analysis of Conversational Code switching". In P. Auer. Code-Switching in Conversation: Language, Interaction, and Identity. London: Routledge. pp. 156-76.

Zhu, H. (2008) Dueling language, dueling values: Code switching in bilingual intergenerational conflict talk in diasporic families. Journal of Pragmatics, 40(10), 1799-1816. doi: https://doi.org/10.1016/j.pragma.2008.02.007. 